\title{
Coastal protection work for Batu Mejan Beach, Bali
}

\author{
Pujianiki Ni Nyoman ${ }^{1 *}$, Astawa Diputra I Gede ${ }^{1}$, Jayantari Made $\mathrm{W}^{1}$, and Mataram $\mathrm{INK}^{1}$ \\ ${ }^{1}$ Department of Civil Engineering, Universitas Udayana, Kampus Bukit Jimbaran, Bali
}

\begin{abstract}
Batu Mejan Beach is an international tourist destination located in the Canggu area of Badung regency, Bali. Due to erosion problems of Batu Mejan Beach the local government installed a revetment system to protect the coast. However, the revetment that was built before for the Batu Mejan Beach is currently ineffective and damaged. To determine the parameters for the construction of a new coastal protection system, the wave energy occurring at the site was evaluated initially as part of this study. A Submerged breakwater with a tetrapod for a protective layer was then chosen as the alternative to reduce the wave energy before reaching the shore and to reduce erosion as well as further deterioration of the existing revetment. A Submerged breakwater is suitable in coastal areas that are used as tourism destinations because the submerged breakwater construction is under the water, therefore the beauty of the beach will not be interrupted. Four models were made with variations in the width and elevation of the breakwater peak. The model was selected which has the minimum value of transmission coefficient and minimum cost. The cost budget plan was determined by using the analytical list of the Public Works and Housing Regulations of 2016. From the analysis, a model was selected with a submerged breakwater height of $2.45 \mathrm{~m}$, length of $110 \mathrm{~m}$, distance gap of $55 \mathrm{~m}$, and the budget of IDR 17,861,989,813.
\end{abstract}

\section{Introduction}

Bali is one of the islands in Indonesia which has beautiful beach panorama and visited by many foreign and domestic tourists for a vacation. According to [1], for the people of Bali, besides as a place of recreation, beaches also functioned as religious places, fishery, and living places. Considering the function and value of the beach in Bali is very important, so the eroded process that still happened need to be concerned and a serious effort have to carried out by Government and society.

The regency of Badung, located in the southern part of Bali Island, has a coastline of 64 $\mathrm{km}$, but along its $12.10 \mathrm{~km}$ beach has eroded [2]. Batu Mejan beach is one of the beaches in the area of Canggu, Badung regency which is visited by many foreign tourists to do activities such as surfing and recreation. According to [3], that erosion has occurred in Batu Mejan beach at a rate of $0.5-1.0 \mathrm{~m} /$ year. To protect these coastal areas from coastal erosion, local governments have developed revetments. Revetment built in Batu Mejan Beach has

*Corresponding author: pujianiki@civil.unud.ac.id 
not been effective and failed as shown in Fig. 1. In general, this damage is caused by scouring at toe protection due to the wave attack. To reduce the impact of further damage, additional coastal protection is needed to reduce wave energy go to the coast. One of the alternatives chosen is a submerged breakwater because submerged breakwater construction is under the water, therefore the beauty of the beach will not be interrupted and the wave energy to the coast is also reduced. Artificial stones are used as breakwater because the availability of natural stone is limited. Natural stone exploitation tends to be unfriendly to the environment and there has been a ban on exploitation of natural stones in some areas in Bali. Tetrapod is selected as a protective layer because it has good interlock properties and is heavy enough to withstand wave energy. The purpose of this research is to plan the dimension and cost budget plan of submerged breakwater construction with the artificial stone material (tetrapod) to reduce wave energy at Batu Mejan beach, Bali.

Submerged breakwater is one of the best types of breakwaters used in coastal areas that are used as tourism destinations. According to [4], the offshore series breakwater is preferred over a single breakwater due to: it is cheaper to build a series breakwater because the gap between the breakwater can reduce the construction material used and the gap in the series breakwater allows for water exchange between onshore and offshore. Tetrapod has a simple shape that produces superior workability, and high stability to wave action because of the strong interconnectedness between each block makes the structure stable. Japan is the most productive tetrapod user with nearly 50 percent of its $35,000 \mathrm{~km}$ coastline has been closed or modified by tetrapod and other concrete forms. In Bali tetrapod is used as a breakwater material in handling coastal erosion in Tanah lot and is used as a breakwater material on the runway of Ngurah Rai Airport.

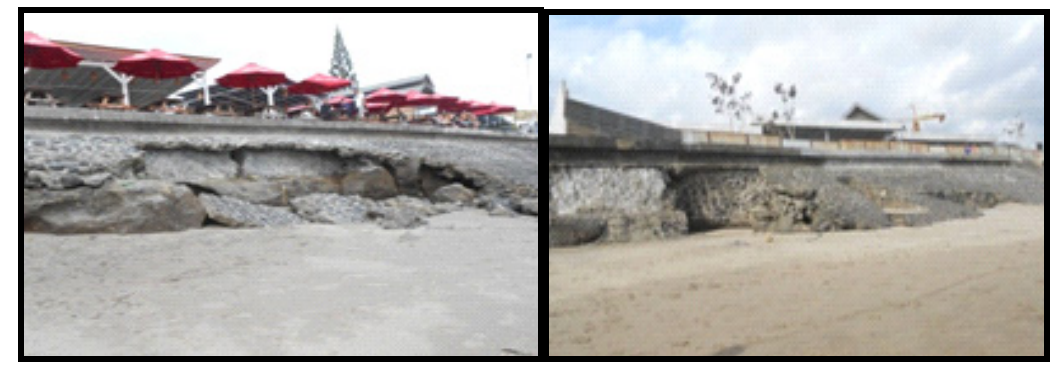

Fig. 1. Existing of revetment damage.

\section{Design method}

Data collected from survey results and secondary data. The collected data which reflect the location of the study is then analysed. Data collected includes:

1) Data on Topography and Bathymetry, obtained from the Bali-Penida River Regional Office, Directorate General of Water Resources, Ministry of Public Works and this data to find out the depth of the seabed and the shape of the seabed.

2) Data Direction and Wind Speed. Wind data is obtained from Meteorology Climatology and Geophysics Ngurah Rai Council. Data in the form of wind data from 2007 to 2016. Wind data obtained used to predict the height and direction of wave plans for the design of breakwater structures.

3) Wave data. Wave data is data consisting of wave forecasting and breaking wave analysis data obtained from the results of wind data analysis. 
4) Data fetch. This data is the result of plotting data from the planning location between an island on the map, to obtain a fixed-point distance to another island in order to obtain the fetch distance as a wave generation.

5) Tidal Data. Obtained from the Bali-Penida River Regional Office, Directorate General of Water Resources, Ministry of Public Works. This data is used to determine the High-Water Level (HWL), Mean Water Level (MSL) and Low Water Level (LWL).

\subsection{Wind and wave data analysis}

Wind data will be analyzed to obtain the wind rose, then the dominant wave direction, and wave height can determine. Based on wind stress factor and effective fetch, the significant wave height and wave period can be calculated using the equation:

$$
\begin{gathered}
H s=\frac{0.016 \times\left(\sqrt{\frac{g F_{\text {eff }}}{U A^{2}}}\right) \times U A^{2}}{g} \\
T s=\frac{0.02857 \times\left(\sqrt{\frac{g F_{\text {eff }}}{U A^{2}}}\right)^{\frac{1}{2}} \times U A^{2}}{g}
\end{gathered}
$$

Shallow Sea Waves then calculated using:

$$
H=K s . K r . H s
$$

\subsection{Submerged breakwater dimensions}

The weight of the protective layer grains can be calculated using the equation:

$$
W=\frac{\gamma r \cdot H^{3}}{K D(S r-1)^{3} \cot \theta}
$$

with a width of the peak:

$$
B=n \cdot K \Delta\left(\frac{W}{\gamma r}\right)^{1 / 3}
$$

and the thickness of the layer:

$$
t=n \cdot K \Delta\left(\frac{W}{\gamma r}\right)^{1 / 3}
$$

where $K_{D}=$ stability coefficient $=5.5$ and $n=$ number of stone layer and $k_{\Delta}=$ coefficient layer $=1.04$ [5]. Length of the breakwater (Ls) calculated using the equation Ls/Y $=0.5-0.6$ where $\mathrm{Y}$ is the breakwater distance from the coastline to the design depth. Calculation of the gap by $\mathrm{L}_{g a p}=0.5 \mathrm{x} \mathrm{Ls}$, and then control the value of transmission coefficient with Tanaka graph as shown in Fig. 2 and Sea Water Level Design was determined based on tidal, wave set up, and sea level rise:

$$
\mathrm{DWL}=\mathrm{Tidal}+\mathrm{Sw}+\mathrm{SLR}
$$




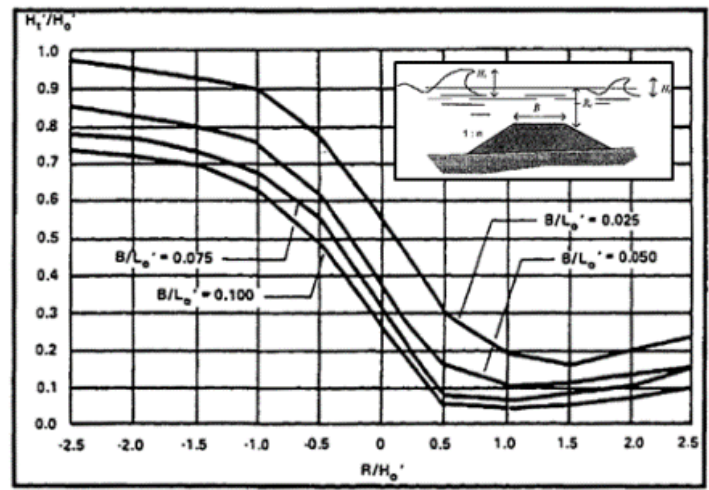

Fig. 2. Transmission coefficient on submerged breakwater [6].

\subsection{Drawing and budget plan analysis}

The design drawing is made based on the type of construction used and the calculation results obtained. Four models are made with the variation of width and elevation of breakwater peak. The cost budget plan for each series of submerged breakwater model calculated based on the unit price analysis from the Public Works and People's Housing Regulation in 2016.

\section{Results and discussion}

\subsection{Wind analysis}

Wind data for duration 2007-2016 from BMKG analyzed to know the percentage of dominant wind direction. Fig. 3 shows that the dominant wind direction blew from the west of $38.33 \%$. Wind stress factor $(\mathrm{UA})=16.27 \mathrm{~m} / \mathrm{s}$.

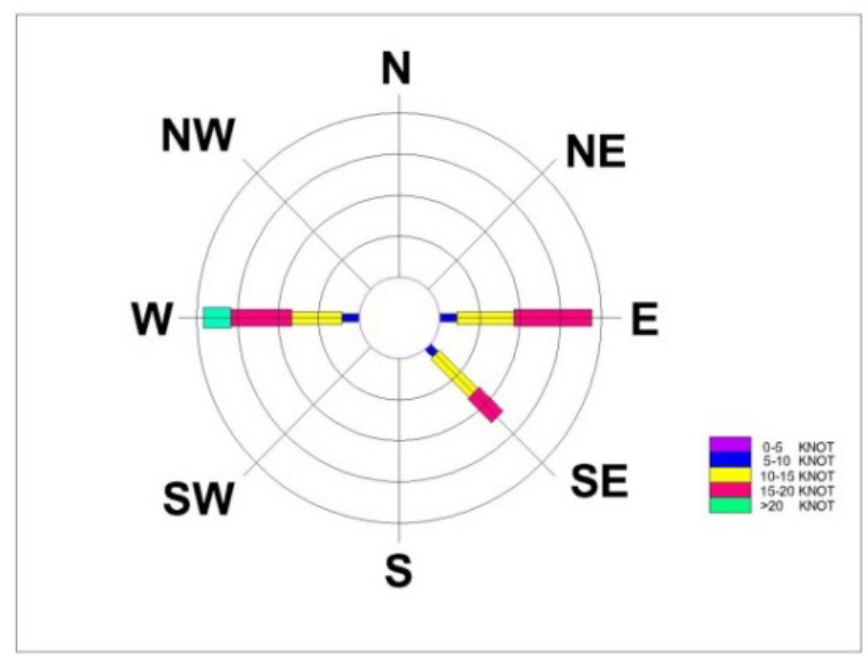

Fig. 3. Windrose analysis in the year of 2007-2016. 


\subsection{Wave analysis}

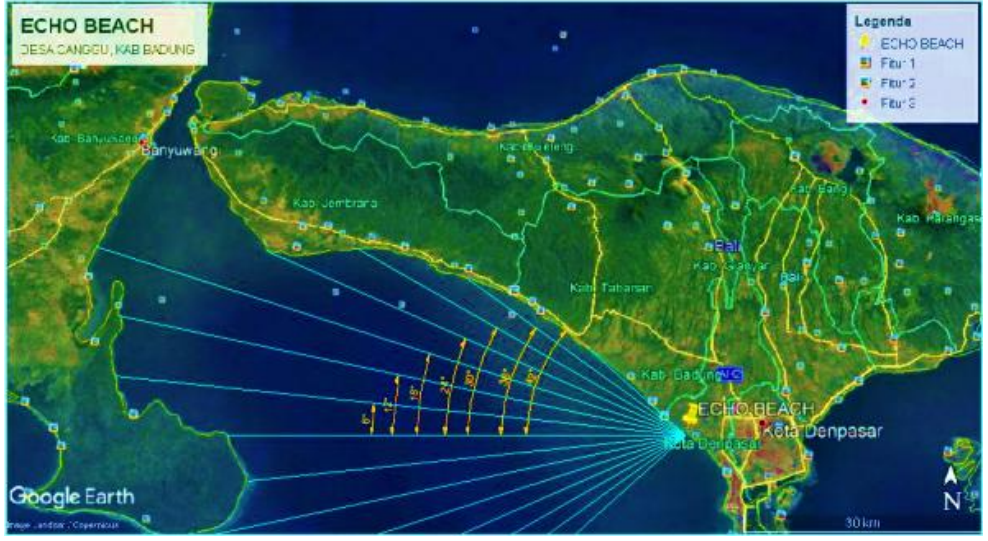

Fig. 4. Fetch of Batu Mejan beach.

The formation of waves by wind is measured from the potential distance of wave formation between the study sites and the islands facing it. Batu Mejan beach has a fetch from the West. The following is an effective fetch calculation for Batu Mejan beach taken from the map of Bali Island and created lines with angles from 60-420, then calculated the length of the line from the shore point to the limiting islands. An effective fetch calculation is outlined in Fig. 4.

From the picture above, effective fetch value was calculated as follow: $F_{\text {eff }}=\frac{\sum x i \cdot \cos \alpha}{\sum \cos \alpha}=\frac{578.97}{8.251}=70.170 \mathrm{~m}$

Significant wave height (Hs) and period (Ts) determine by Eq. (1) and (2) with results $\mathrm{Hs}=2.2 \mathrm{~m}$ and $\mathrm{Ts}=6.52 \mathrm{~s}$.

Subsequently, calculation of maximum wave height using two methods namely Gumbel method (Fisher Tippett Type I) and Weibull method was conducted with return period for 25 years. The selected the method has correlation value of closer to 1 . In this planning we used Gumbel method (Fisher Tippett Type I), with a result of wave height equal to $2.385 \mathrm{~m}$ and period equal to 6.713 seconds then wavelength and wave celerity in deep water can be calculated as follows:

$$
\begin{aligned}
& \mathrm{Lo}=\frac{g T^{2}}{2 \pi}=1.56 \times \mathrm{T}^{2}=\frac{9.81 \mathrm{~m} / \mathrm{s}^{2} \times(6.713 \mathrm{~s})^{2}}{2 \times 3.14}=70.301 \mathrm{~m} \\
& \mathrm{Co}=\frac{g T}{2 \pi}=1.56 \times \mathrm{T}=\frac{9.81 \mathrm{~m} / \mathrm{s}^{2} \times 6.713 \mathrm{~s}}{2 \times 3.14}=10.472 \mathrm{~m} / \mathrm{s}
\end{aligned}
$$

Based on the bathimetry map, breakwater is placed at depth $(d)=4.0 \mathrm{~m}$ (usually offshore breakwater is placed at a depth of $1.5-8.0 \mathrm{~m}$ ) [7], then $\frac{d}{L o}=\frac{4 \mathrm{~m}}{70.301 \mathrm{~m}}=0.057$. The value of $\mathrm{d} / \mathrm{Lo}=0.057$, using table $\mathrm{A}-1[5], \mathrm{d} / \mathrm{L}=0.10132$, and finally $\mathrm{L}=39.55 \mathrm{~m}$. The calculated transition sea wave velocity is $\mathrm{C}=5.89 \mathrm{~m} / \mathrm{s}$.

The direction of the wave at 4.0 meters depth calculated by $\sin \alpha=\left(\frac{c}{c_{n}}\right) \sin \alpha_{0}=0.398$ and $\alpha_{1}=23.45^{\circ}$. 
The refraction coefficient is calculated using the equation $\mathrm{Kr}=\sqrt{\frac{\cos \alpha_{0}}{\cos \alpha_{1}}}=0.88$.

To calculate the shoaling coefficient (Ks) is searched by using Table A-1 [5], based on value $\mathrm{d} / \mathrm{Lo}$ above, so that the value of Ks equal to 1.001. The wave height in the shallow seas is due to the influence of wave refraction and wave shoaling were calculated using the Eq. (3), $\mathrm{H}=\mathrm{Ks} \times \mathrm{Kr} \times \mathrm{H}_{\mathrm{t} 25}=1.001 \times 0.88 \times 2.385 \mathrm{~m}=2.1 \mathrm{~m}$.

Wave breaking calculation as follows:

1) Equivalent wave heights. The equivalent wave height at a depth of 4.0 meters is:

$\mathrm{H}^{\prime}{ }_{0}=\mathrm{Kr} \times \mathrm{H}=0.88 \times 2.1 \mathrm{~m}=1.834 \mathrm{~m}$.

2) Height wave breaking can use the following equation.

$$
\frac{H b}{H_{0}^{\prime}}=\frac{1}{3.33\left(H_{0}^{\prime} / L_{0}\right) \frac{1}{3}}=\frac{1}{3.33(1.834 / 70.301) \frac{1}{3}}=1.23 \text { and } \mathrm{H}_{\mathrm{b}}=2.26 \mathrm{~m}
$$

$3)$ The depth of the wave breaking. Based on the slope of Batu Mejan beach ( $m=0.033)$ obtained $a$ and $b$ is a coastal slope function, which is calculated by the equation below:

$$
\begin{aligned}
& a=43.75\left(1-\mathrm{e}^{-19 \mathrm{~m}}\right)=43.75\left(1-\mathrm{e}^{-19 \times 0.033}\right)=20.38, \text { and } \\
& b=\frac{1.56}{\left(1+e^{-19 m}\right)}=\frac{1.56}{\left(1+e^{-19 \times 0.033}\right)}=1.02 \\
& \text { then calculate } \frac{d b}{H b}=\frac{1}{b-\left(\alpha H b / g T^{2}\right)}=1.1 \text { and } \mathrm{db}=2.47 \mathrm{~m} .
\end{aligned}
$$

\subsection{Submerged breakwater dimension}

Based on research conducted by Dally and Pope [8] states that to form salient, both for single breakwaters and series breakers, the following formula is required $\frac{L s}{Y}=0.5-0.6$ then selected 0.5 . The distance of the breakwater structure from the coastline is $\mathrm{Y}=220 \mathrm{~m}$, then the length of breakwater becomes Ls $=0.5 \times 220=110 \mathrm{~m}$. According to the [9] on the requirements regarding the width of a gap between buildings submerged breakwater is Lgap $=0.5 \mathrm{x} \mathrm{Ls}=55 \mathrm{~m}$ (as shown in Fig. 5)

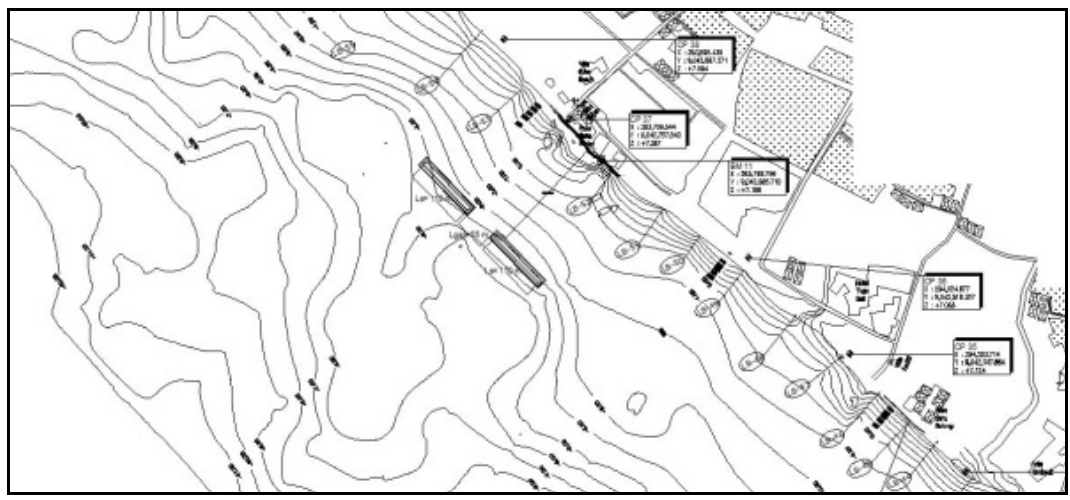

Fig. 5. Layout of submerged breakwater.

The relative mass density $(\mathrm{Sr})$ is the ratio of specific gravity of concrete $(\gamma \mathrm{r})=2.4$ $\operatorname{ton} / \mathrm{m}^{3}$ with the density of sea water $(\gamma \mathrm{a})=1.03$ then $\mathrm{Sr}=\frac{\gamma r}{\gamma \alpha}=2.33$. The weight of the protected layer can be calculated upon knowing the stability coefficient of tetrapod as 
protective layers $\left(\mathrm{K}_{\mathrm{D}}\right)=5.5$ [5] with slope of submerged breakwater structure, $1: 2(\cot \Theta=$ 2 ) as Eq. (4). $\mathrm{W}=0.85$ ton $\approx 1$ ton. The weight of second layer stones: $\mathrm{W}_{2}=\mathrm{W} / 10=0.1$ ton $=100 \mathrm{~kg}$. The weight of core layer stones: $\mathrm{W}_{3}=\frac{W}{400}$ until $\frac{W}{200}=0.0025-0.005$ ton $=$ 2.5-5 kg. Based on [5] and coefficient for tetrapod $\mathrm{K}_{\Delta}=1.04$ and $(\mathrm{n})=5$ so the peak width of the building is calculated by Eq. (5), $\mathrm{B}=3.7 \mathrm{~m}$.

In this study, two alternative widths of the peak structure will be calculated. The first uses a width of $3.7 \mathrm{~m}$ with a ratio of $\mathrm{B} / \mathrm{Lo}=3.7 / 70.301=0.005$ and the second $5.3 \mathrm{~m}$ with a $\mathrm{B} /$ Lo ratio of $5.3 / 70.301=0.0075$. This width will affect the transmission coefficient. The width of the peak of the structure will minimize the wave transmission coefficient since the smaller the transmission coefficient, then the waves leading to the coast will be smaller. The minimum number of rocks $(n)=2$ and coefficient $K_{\Delta}=1.04$ so that the thickness of the layer is calculated by Eq. (6), that is $\mathrm{t}=1.55 \mathrm{~m}$. The second layer thickness is $\mathrm{t}_{2}=$ $2 \times 1.15 \times\left(\frac{0.1 \text { ton }}{2.65 \text { ton } / \mathrm{m}^{3}}\right)^{1 / 3}=0.772 \approx 0.78 \mathrm{~m}$. The number of protective stones for one unit area $\left(10 \mathrm{~m}^{2}\right)$ was calculated by equation $\mathrm{N}=A \cdot n \cdot K \Delta\left(1-\frac{P}{100}\right)\left(\frac{\gamma r}{w}\right)^{2 / 3}$ $=10 \mathrm{~m}^{2} \times 2 \times 1.04 \times\left(1-\frac{50}{100}\right)\left(\frac{2.4 \mathrm{ton} / \mathrm{m}^{3}}{1 \text { ton }}\right)^{2 / 3}=18.64 \approx 19$ stones.

\subsection{Design Water Level (DWL)}

Design water elevation is the sum of several parameters: tidal, sea level rise because of global warming (SLR) and sea level rise due to wind set-up. Design water level (DWL) calculated by Eq. (7). DWL $=\mathrm{LWL}+$ sea level rise $+\mathrm{Sw}=-1.55 \mathrm{~m}+0.25 \mathrm{~m}+0.35 \mathrm{~m}=-$ $0.95 \mathrm{~m}$ where MSL as a reference is \pm 0.00 , (shown in Table 1). Then determined the peak elevation, which in this design was tried using two different peak elevations to obtain submerged breakwater model of transmission coefficient and cost-effective budget plan. The first elevation is assumed to be placed at $-0.95 \mathrm{~m}$. This shows that on the mean water level submerged breakwater is submerged as deep as $0.95 \mathrm{~m}$ and when receded will appear at $0.65 \mathrm{~m}$. The second elevation is assumed to be placed at $-1,55 \mathrm{~m}$. This shows that on the mean water level submerged breakwater is submerged as deep as $1.55 \mathrm{~m}$ and will not appear at low tide.

Tabel 1. Water level elevation to MSL.

\begin{tabular}{|c|c|}
\hline Elevation of reference & Elevation (m) \\
\hline HWL & $+1,55$ \\
\hline MWL & $+0,00$ \\
\hline LWL & $-1,55$ \\
\hline
\end{tabular}

\subsection{Simulation of model}

There are four models with different peak elevations and different widths to get design drawings that have small transmission coefficients and low cost. 


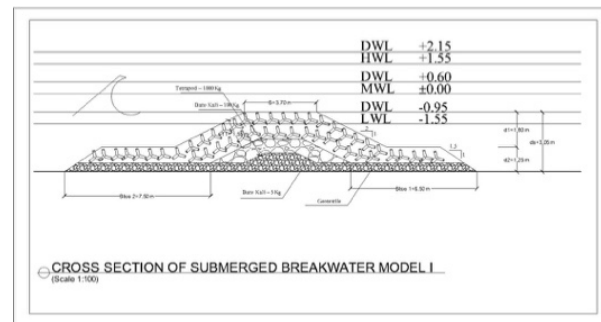

(a)

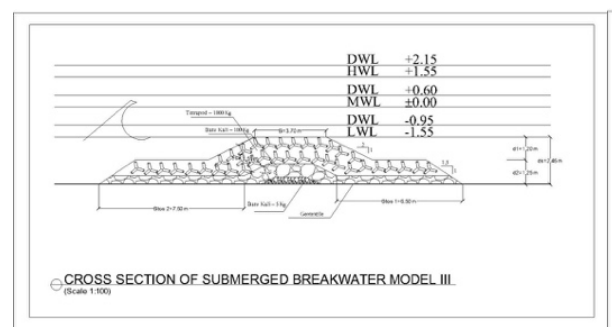

(c)

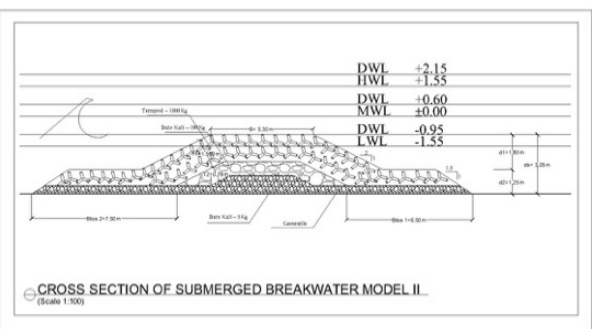

(b)

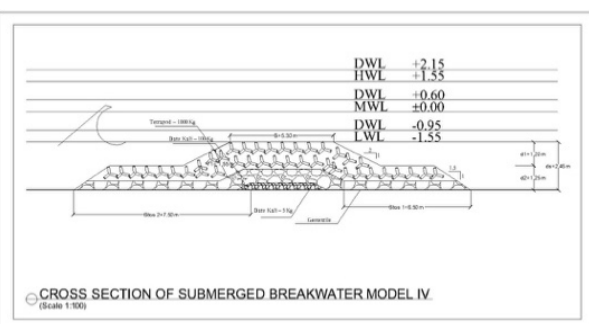

(d)

Fig. 6. Model of simulation (a) Model 1, (b) Model 2, (c) Model 3, (d) Model 4.

The transmission coefficient $(\mathrm{Kt})$ is defined as the $\mathrm{Hi} / \mathrm{Ht}$ which $0<\mathrm{Kt}<1$, with value 0 means no transmission (high, watertight), and value 1, implies a complete transmission (no breakwater). In this study, the transmission coefficient is calculated by using the Tanaka graph. Model I was placed at an elevation -0.95 with a width of $3.7 \mathrm{~m}$, Model II was placed at an elevation -0.95 with $5.3 \mathrm{~m}$ wide, Model III was placed at elevation -1.55 with a width of $3.7 \mathrm{~m}$, and Model IV is placed at elevation -1.55 with $5.3 \mathrm{~m}$ wide as shown in Fig. 6.

Table 2. Selection of submerged breakwater model.

\begin{tabular}{|c|c|c|c|c|}
\hline Parameter & Model I & Model II & Model III & Model IV \\
\hline Peak elevation (m) & -0.95 & -0.95 & -1.55 & -1.55 \\
\hline Peak width (m) & 3.70 & 5.30 & 3.70 & 5.30 \\
\hline Range of Kt value & $0.24-0.80$ & $0.18-0.73$ & $0.38-0.82$ & $0.32-0.75$ \\
\hline $\begin{array}{c}\text { Range of Ht value } \\
\text { (m) (Hi=2,1 m) }\end{array}$ & $0.502-1.674$ & $0.377-1.528$ & $0.795-1.716$ & $0.670-1.569$ \\
\hline $\begin{array}{c}\text { Project cost (Rp) } \\
\text { inclune 10\% tax }\end{array}$ & $19,562,173,724$ & $21,756,071,248$ & $15,251,301,061$ & $17,861,989,813$ \\
\hline $\begin{array}{c}\text { Cost per m (Rp) } \\
\text { Rank for the Kt } \\
\text { value }\end{array}$ & $88,918,971$ & $98,891,233$ & $69,324,096$ & $81,190,863$ \\
\hline $\begin{array}{c}\text { Rank for the project } \\
\text { cost }\end{array}$ & 3 & 1 & 4 & 2 \\
\hline Average rank & 3 & 4 & 1 & 2 \\
\hline
\end{tabular}


Based on analysis using Tanaka graph, the transmission coefficient for each model as follows are the result of transmission coefficients of Model I ranging from 0.24-0.8, model II 0.18 to 0.73 , model III 0.38 to 0.82 , and model IV 0.32 to 0.75 . Comparing the four models and ranking 1 to 4 for the transmission coefficient and the budget plan of each model then selected the smallest average ranking as can be seen in Table 2. Model IV has the lowest average rating with a small enough transmission coefficient value that means Model IV can reduce wave energy reaching the coast and has enough minimal project cost. Then the submerged breakwater planning in Batu Mejan beach is used model IV.

\section{Conclusions}

Submerged Breakwater with $2.45 \mathrm{~m}$ height, $110 \mathrm{~m}$ length, and $55 \mathrm{~m}$ gap had designed with budget plan IDR 17,861,989,813.00. Before this model is applied at the location, its need to be modeled first to know the effects of the submerged breakwater in reducing wave energy in Batu Mejan Beach.

This research publication is supported by The USAID SHERA Program for Universitas Indonesia's Scientific Modeling Application, Research and Training for SMART CITY Project GRANT \#AID497-A-1600004, Sub Grant \#IIE-00000078-UI-1

\section{References}

1. N.N. Pujianiki, Berkala Ilmiah Teknik Keairan 13, 3 (2007)

2. Ministry of Public Works of the Directorate General of Water Resources of the Republic of Indonesia, The Preparatory Survey on Bali Beach Conservation ProjectPhase II in the Republic of Indonesia (Ministry of PublicWorks Republic Indonesia, Jakarta, 2013)

3. BLH Bali Province, Regional environmental status (SLHD) of Bali province (Bali Province Government, Bali, 2015)

4. R.G. Dean, R.A. Dalrymple, Coastal process with engineering applications (Cambridge University Press, Cambridge, 2004)

5. B. Triatmodjo, Coastal engineering (Beta Offset, Yogyakarta, 1999)

6. N. Tanaka, Proceedings of $23^{\text {rd }}$ Japanese Conf. of Coastal Engineering JSCE (1976)

7. US Army Coastal Eng. Research Center, CERC shore protection manual (US Army Corps of Engineers, Washington DC, 1984)

8. Department of the US Army Corps of Engineers, Engineering and design coastal engineering manual (US Army Corps of Engineers, Washington DC, 2002)

9. Public Works Department, Coastal protection design manual (Sea Defence Consultant, Aceh, 2009) 